\title{
Analysis on the Operation Model and Development Strategy of Theme Parks in Wuhan
}

\author{
Xiaoman $\mathrm{Guo}^{1, *}$ \\ ${ }^{1}$ Business School, Wuchang University of Technology, Wuhan, Hubei 430000, China \\ *Corresponding author. Email: 632490065@qq.com

\begin{abstract}
In view of the saturation of theme parks in China's first-tier cities, the prospective strong demand for tourism in second-tier cities, coupled with the low land price and operating cost in second-tier cities, the theme parks are gradually penetrating into second-tier cities. As a central city in central China, compared with first-tier cities, Wuhan enjoys reasonable land price given its economic development, and relatively low operating cost, putting it in a favorable position to promote theme parks. This paper analyzes the spatial layout, theme types and investment and development status of theme parks dotted in Wuhan, discovers existing problems in their operation, and then puts forward specific strategies for their development.
\end{abstract}

\section{Keywords: theme park, operation model, development strategy}

\section{INTRODUCTION}

There are more than 15,000 theme parks in China, mainly distributed in the Pearl River Delta, the Yangtze River Delta, and Beijing. Among them, the Pearl River Delta region is mainly represented by Shenzhen Overseas Chinese Town, which has four theme parks: Happy Valley with entertainment and interesting experience as the theme, Window of the World themed ancient and modern scenic spots and wonders inside and outside China as the window of the world, Splendid China with time-honored Chinese history and culture and natural resources, as well as China Folk Culture Village that showcases folk architecture, art and customs. Despite their different themes, the four theme parks all are based on the cultural core. The Yangtze River Delta region is mainly represented by Song Cheng in Hangzhou and $\mathrm{Wu}$ Cultural Park in Wuxi. Among them, the former, themed with Songcheng culture, takes "architecture as form, culture as soul" as its management concept, integrating culture, amusement and technology; while the latter with patriotism education as the theme, reveals the culture and folk customs of $\mathrm{Wu}$ for thousands of years. As the political, economic and cultural center of China, Beijing boasts a variety of theme parks, most of which are entertainment, which reflects Beijing's positioning of theme parks as recreation and entertainment. The theme parks with folk culture and ancient literature drama as theme account for a large proportion, which reflects the rich historical and cultural resources of Beijing. In addition, the city attaches great importance to the development of cultural theme parks, which are mainly located in the urban areas, with few in the suburbs, so there is still a lot of room for development in the suburbs. It's obvious from the above that the development of theme parks across China has been industrialized and diversified, forming an industry with culture as the core, integrating theme parks, theme hotels and theme cultural products.

Given the saturation of theme parks in first-tier cities, it is imperative to develop theme parks in Wuhan. As the central city in central China, the secondtier city enjoys favorable economy and transportation, strong future demand for tourism, and relatively low land and operating costs.

\section{DEVELOPMENT STATUS OF THEME PARKS IN WUHAN}

\section{A. Analysis of spatial distribution}

At present, there are 19 major theme parks in Wuhan, of which 15 are located in the central city area, and only 4 are in distant suburban area. The theme parks are relatively evenly distributed in the central city area. There are theme parks in distant suburban area with small number. The development of theme parks in Xinzhou District, Caidian District and Hannan District is relatively weak and needs to be developed.

Thanks to the urban development, the central city enjoys convenient transportation, large population density and strong innovation consciousness. Therefore, the theme parks in this area were built earlier, developed more perfectly, and the spatial layout is more reasonable. However, with the rapid development of Wuhan and the expansion of city circle, the distant 
suburban area has greater potential, and theme parks will gradually penetrate into there in the future. At present, a number of enterprises has showed interest in building theme parks in distant suburban area of
Wuhan, which has a lot to do with the large land demand of theme parks, the saturation of theme parks in central city, the availability of land in distant suburban area and the relatively cheap land price. ("Table I")

TABLE I. SPATIAL DISTRIBUTION MAP OF MAJOR THEME PARKS IN WUHAN

\begin{tabular}{|c|c|c|c|c|c|c|c|c|c|}
\hline & \multicolumn{3}{|c|}{ Central area } & \multicolumn{6}{|c|}{ Distant suburban area } \\
\hline District & Hankou & Hanyang & Wuchang & $\begin{array}{c}\text { Dongxihu } \\
\text { district }\end{array}$ & $\begin{array}{c}\text { Jiangxia } \\
\text { district }\end{array}$ & $\begin{array}{c}\text { Huangpi } \\
\text { district }\end{array}$ & $\begin{array}{c}\text { Xinzhou } \\
\text { district }\end{array}$ & $\begin{array}{l}\text { Caidian } \\
\text { district }\end{array}$ & $\begin{array}{c}\text { Hannan } \\
\text { district }\end{array}$ \\
\hline Quantity & 3 & 4 & 8 & 2 & 1 & 1 & 0 & 0 & 0 \\
\hline Total & \multicolumn{3}{|l|}{15} & \multicolumn{6}{|l|}{4} \\
\hline
\end{tabular}

\section{B. Analysis of theme type}

The author consulted materials concerning the types of theme parks in China and abroad, and divided theme parks in Wuhan into six categories: entertainment, natural ecology, culture and history, popular science, animal viewing, and sports culture. Among them, the entertainment category accounts for $36.8 \%$. The development of theme parks in Wuhan focuses on entertainment, leisure and experience-oriented. The parks belonging to natural ecology with flower as theme have problems such as theme repetition and similar operation mode. Known as "river city", Wuhan boasts beautiful and natural landscape, flowers, trees, and lakes. Obviously, the investors of this type of theme parks fail to make in-depth development of such urban natural resources, blindly imitate and follow the trend, which leads to the serious homogeneity of products and lack of personality. Culture and history category only account for $15.8 \%$. What's worse, the three theme parks have small scale, single theme products and stereotyped operation mode. As a national historical and cultural city, Wuhan has failed to develop its rich cultural and historical resources in depth. The deep integration of local cultural history and theme parks needs to be improved. As a "thoroughfare of nine provinces", Wuhan fails to well utilize its superior geographical position, economic status and cultural history. ("Table II")

TABLE II. THEME TYPES OF MAJOR THEME PARKS IN WUHAN

\begin{tabular}{|c|l|l|l|l|l|l|l|}
\hline Theme types & Entertainment & $\begin{array}{c}\text { Natural } \\
\text { ecology }\end{array}$ & $\begin{array}{c}\text { Culture } \\
\text { and } \\
\text { history }\end{array}$ & $\begin{array}{c}\text { Popular } \\
\text { science }\end{array}$ & $\begin{array}{c}\text { Animal } \\
\text { viewing }\end{array}$ & $\begin{array}{c}\text { Sports } \\
\text { culture }\end{array}$ & Total \\
\hline Quantity & 7 & 4 & 3 & 2 & 2 & 1 & 19 \\
\hline Proportion & $36.8 \%$ & $21.1 \%$ & $15.8 \%$ & $10.5 \%$ & $10.5 \%$ & $5.3 \%$ & $100 \%$ \\
\hline
\end{tabular}

\section{Analysis of investment and operation status}

The overall investment scale of theme parks in Wuhan is relatively small, with nearly $80 \%$ of the investment in theme parks less than 200 million yuan. There are three major theme parks: Wuhan Haichang Ocean Park, Wuhan Happy Valley and Wanda Wuhan Movie Park Entertainment. It is reported that Wuhan Haichang Ocean Park has invested a huge sum of 3 billion yuan to build a new ocean ecology international community of 1.06 million square meters with the theme of polar and ocean. The construction marine venues cost 700 million yuan. Its completion and opening means the arrival of a new era of Wuhan tourism theme park, attracting crowds of families and college students. As a tourist landmark of Wuhan, Happy Valley has been operating well since its opening in 2012. On Halloween in 2017, it received 44,900 visitors throughout the day and 41,000 at night, breaking the previous record for a single day in 2017. In the golden week of National Day in 2018, the total number of visitors reached 160,000 , which doubled the number of visitors in the same period in 2017. Wanda group invested 3.8 billion yuan to build the Wanda Wuhan Movie Park Entertainment, which was completed and opened in 2014. The average daily visitor volume was about 200 people, which failed to reach the expected 1,000 people, and the capital could not be recovered in a short time. Subsequently, it was closed for rectification in 2016 and opened for only 19 months. Judging from the current operating situation, there are only two large-scale theme parks in Wuhan that are well-operated, and there is still a big gap compared with the first-tier cities such as the Pearl River Delta, the Yangtze River Delta, and Beijing. As for the development of theme parks, Wuhan needs not only to increase investment, but also to formulate 
appropriate operating strategies to increase the average daily visitor flow and income of theme parks.

\section{PROBLEMS IN THE OPERATION MODEL OF THEME PARKS IN WUHAN}

\section{A. Theme parks are not well-known brands}

The lack of locally branded theme parks. At present, the two well-developed theme parks in Wuhan, Happy Valley and Wuhan Haichang Ocean Park, are foreign chain brands. The same is true of the many theme parks that will be settled in the future. As a result, greater efforts are needed to develop locally branded theme parks. Judging from the scale of the 19 theme parks currently built in Wuhan, most of them are regional, urban, and community-level. The main customer groups are the residents of the city and its surrounding areas, and few tourists from other regions come to visit. For example, Guangzhou Chimelong Theme Park is a local brand with great popularity and many tourists from other places are attracted to it.

\section{B. Lack of innovation in the design and development of theme park products}

There are only six types of theme parks in Wuhan, and each type of theme has serious homogeneity and lacks creativity. For example, there are three parks themed natural ecology: rose theme park, tulip theme park and lavender theme park, all of which focus on flower appreciation, creating ecological sightseeing scenic spots with similar operation modes and poor creativity. Theme parks should take culture as the core and soul, integrate unique culture into tourism resources, and then present unique cultural tourism products. The design concept of such products should be deeply combined with local culture, history, economic status and scientific and technological level to understand the needs of products or services from the perspective of tourists. The needs of tourists should be classified to meet the basic needs of the target tourist group and develop and design products or services. As time goes by, when the basic needs of tourists are satisfied, the product or service design needs to be constantly updated to meet the expectation and excitement needs of tourists and attract tourists to visit for many times.

\section{The centralization of theme park sites}

With the development of city and the expansion of city circle, the land price and commodity price of the central city are high. The theme parks occupy a large area. Most of the theme parks in Wuhan are in the central city, and few in distant suburban area. The longterm development of theme parks will inevitably encounter serious cost problem. For example, Wanda Wuhan Movie Park Entertainment, located in the core business district, failed to meet the expected passenger flow, coupled with high operating costs, so it was suspended from operation after only 19 months for rearrangement. The selection of location mainly explains its failure.

\section{Restrictions on historical culture and natural resources}

Wuhan is a tourist attraction with long history and culture, many scenic spots and historical sites, and abundant natural resources. Yellow Crane Tower is the most famous historical site in Wuhan. The ancient Guqin Terrace is the place where Boya plays musical instrument and Zhong Ziqi listens the rhyme, which passed down from generation to generation. Wuhan is rich in mountain and river. The Yangtze river runs across the city, and there are many lakes. The east lake is a large scenic area in Wuhan, with beautiful environment and rich history and culture, which has become a popular destination for tourists. This, in turn, has dampened the development of Wuhan's theme parks.

\section{DEVELOPMENT STRATEGY OF THEME PARKS IN WUHAN}

Home to 14 million, Wuhan is rich in natural resources, historical and cultural resources. Traditional leisure, entertainment and ornamental parks can no longer meet the daily tourism needs of residents, so it is necessary to combine local resources, science and technology, culture and economy to create themed parks to enrich people's lives and meet their needs. Theme parks are often involved in the consumption behavior, consumption capacity, theme play and so on of tourists. The operation needs to strike a balance between leisure, entertainment and experience. The operation mode of enterprises needs constant innovation to attract tourists.

\section{A. Focusing on the building and marketing of theme park brand}

Wuhan should establish locally branded theme parks, pay attention to the construction and promotion of the brand, establish the brand image of theme parks. The theme must be highlighted in brand positioning, packaging, and publicity to present visitors a clear, precise and attractive brand image. The establishment of the brand must combine with the cultural and historical characteristics of Wuhan to create unique brand image for theme parks here. Marketing methods must be combined with the current popular marketing channels for precision marketing. Apart from the surrounding residents, the customer group should be expanded to national scope. Therefore, the choice of marketing strategy and marketing channels should be paid special attention. 


\section{B. Formulating enterprise strategy and operation strategy}

An enterprise without strategy is like driving in a strange place without map or navigation. Enterprise strategy is the core of decision-making, guiding the enterprise to achieve the desired goals. Therefore, the development of theme parks requires reasonable enterprise strategy and operation strategy. According to survey, residents are only interested in theme parks for about three years, so it is necessary for enterprises to keep innovating in operation model, make highlights, so as to retain the surrounding tourists and attract nonnative tourists. The formulation of enterprise operation strategy should first meet the basic needs of tourists, that is, to ensure order qualifier, and then focus on the expectation-type demand and excitement-type demand, in order to identify and cultivate order winner of enterprises, thus forming the unique competitiveness of enterprises.

\section{Focusing on internal management}

The income of theme parks depends on tourist flow, so tourists are God. Tourist satisfaction is vital for the long-term development of theme parks. Therefore, theme parks are required to strengthen service management and innovation, to well utilize high-tech means to serve tourists in the information age, and adhere to the people-oriented principle, such as: online ticket, online car rental, reservation, online reservations, traffic information tips, voice guide, so that tourists experience the high-tech service and its convenience. Tourists' satisfaction should be valued, and tourists should be visited regularly, so as to continuously improve product design and carry out service innovation.

Given the poor education background of employees in theme parks, it is needed to make reasonable management plan. The first is to cultivate corporate culture, enhance the cohesion and sense of mission of employees, encourage them to treat tourists with the concept of ownership, improve their service awareness; The second is to strengthen training, establish reasonable staff training system, carry out training in the aspects of service, safety, innovation, promotion and so on, to constantly improve their personal ability, service awareness and innovative thinking; The third is to clarify the path of promotion for employees, and formulate incentive, assessment and promotion plans to encourage them to work hard and continuously improve, so as to reserve available talents for the longterm development of theme parks.

\section{Building industrial chain of theme parks}

The development of theme parks in Wuhan needs to take strong historical culture as the core and integrate cultural characteristics into local tourism resources. The development of theme parks from park planning, product design, park construction, operation and management as a whole industrial chain should be realized vertically. The theme brand will be extended horizontally, supporting the development of catering industry, theme hotels, real estate and other diversified industries, to realize the value increment of theme brand, and improve the comprehensive strength. For example: Shenzhen Overseas Chinese Town, led by four major theme parks, starts a new mode of cultural tourism, constructs the differentiation of real estate business, and integrates tourism with the Internet to form its own cultural industry chain.

\section{CONCLUSION}

In short, Wuhan has great advantages in developing theme parks. As for the geographical location, Wuhan's convenient transportation, coupled with the development concept of Wuhan's " $1+8$ " urban circle, not only radiates in Hubei Province, but also drives the surrounding provinces of Anhui, Hunan, Shaanxi, and Henan. As regard to resources, the city boasts numerous mountains, rivers and lakes, flowers and trees, profound history and culture, and rich tourism resources. Judging from the level of economic development, the land price in Wuhan matches the scale of its economic development, and its land price and operating cost are lower than those in first-tier cities. At present, the development of theme parks in this region has achieved certain scale, but there are still big problems in operation, which requires the region to combine its own advantages with the development process of theme park industry, so as to promote the rapid development of the industry.

\section{References}

[1] Yang Guihua. Research on the Model of Thematic Garden [J]. The Ideological Front(Yunnan University's Journal of Social Sciences). 2002, (06). (in Chinese)

[2] Liu Chunling, Zhou Desheng. China urban theme park's operating mode and development countermeasure research taking Beijing theme park as example [J]. Special Zone Economy. 2008. (in Chinese)

[3] Jia Jianzhong. Types, Characteristics and Development Orientation of Theme Park at Home and Abroad [J]. Beijing City Planning \& Construction Review. 2003. (in Chinese)

[4] Wu Furong. A Probe into the Development of the Cultural Tourism Resources in China [J]. Journal of Nanjing University of Finance and Economics. 2005, (02). (in Chinese)

[5] Li Zhou, An Analysis of the Tourists' Survey in the Overseas Chinese Town in 2000 - On the Development of China's Theme Parks [J]. Tourism Tribune, 2001. (in Chinese)

[6] Song Ning, Research on the Development Strategy of Theme Parks in China [J]. Art Science and Technology, 2015. (in Chinese) 